\title{
Engagement without accountability: The role of governments, field experts, and public intellectuals in the context of the covid-19 pandemic*
}

\author{
B. Radeljić1,2, C. González-Villa ${ }^{3}$ \\ ${ }^{1}$ Necmettin Erbakan University \\ Dere Aşıklar Mah., Demeç Sok. No 39/1, 42140 Meram/Konya, Turkey \\ ${ }^{2}$ Antonio de Nebrija University \\ 27 Calle Santa Cruz de Marcenado, 28015 Madrid, Spain \\ ${ }^{3}$ Universidad de Castilla-La Mancha \\ Cobertizo de San Pedro Mártir S/N, 45071 Toledo, Spain \\ (e-mail: radeljic@erbakan.edu.tr; BRadeljic@nebrija.es; Carlos.GonzalezVilla@uclm.es)
}

\begin{abstract}
The outbreak of the covid-19 pandemic represented a major shock. In their effort to adapt their responses to the crisis to their own conditions of survival, governments have tended to resort to arguments that limit accountability to the population. Despite the privileged place they are presumed to have within contemporary societies, experts have been displaced from the decisionmaking processes of governments and delegitimized by the anti-intellectual drift favored by the way in which arguments are presented and debated in social media. At the same time, despite being perceived as capable of offering inside-out evaluations of specific phenomena and therefore capable of distinguishing between truths and big lies (and anything in-between), the role of public intellectuals seems to have been limited. The article analyses the responses of great power governments and regional powers in terms of the discursive practices deployed in the context of the covid-19 crisis, and the capacity of the aforementioned non-institutional actors to confront these discourses. As 'editors-in-chief', policymakers have felt passionate about war metaphors that have allowed them to deconstruct and make complex subjects accessible, and as such, to ensure a sufficient level of attention and public approval so that the fight against the enemy could begin. In addition, they have prompted the implementation of emergency measures that, in a context of geopolitical confrontation, have allowed them to evade individual responsibilities. Rather than using their knowledge to provide constructive examination of complex issues and make them accessible, so the ones who listen to them can hopefully understand the impact of specific policy preferences and minimize their own losses in the increasingly competitive environment, experts and intellectuals have seen their room for maneuver to influence policy formulations severely limited.
\end{abstract}

Key words: covid-19; executive power; field experts; public intellectuals; war metaphor; securitization

The outbreak of the covid-19 pandemic represented a major shock. The initial accounts, mostly focusing on bats as common transmitters and Chinese wet markets (with the one in Wuhan at the forefront) as epicenters of zoonotic diseases, served to stress the intertwined character of human-nature relations, as well as the potential

* (C) B. Radeljić, C. González-Villa, 2021

The article was submitted on 31.05.2021. The article was accepted on 28.09.2021. 
consequences once the red line has been crossed. Talking about the connection between the killing of nature and future types of illnesses, some UN officials sought to warn the global community that "the message we are getting is if we don't take care of nature, it will take care of us" [18]. Other observers used similar warnings to depict the coronavirus storm as "nature's pro-active response to the suicidal behavior of homo not-so-sapiens" [65]. The consequent images of medical staff covered in personal protective equipment and severe lockdown measures, introduced around the globe to prevent the spread of coronavirus, consolidated the narrative that the world had no other choice but to enter into a war against the new enemy. Accordingly, Chinese President Xi Jinping was "the commander of the people's war against the epidemic" [77] and US President D. Trump described himself as 'a wartime president' who had to win the 'war against the Chinese Virus' so that the US "can immediately go right back up to where it was, and even beyond". In Europe, British Prime Minister B. Johnson stressed that his government had to behave 'like any wartime government', French President E. Macron declared that 'France was at war', and German Chancellor A. Merkel addressed her fellow citizens by saying that the country was facing its biggest challenge since the Second World War [48].

While relying on their closest associates, key ministries, and state agencies, but also on non-state actors (especially the social media outlets, because of their capacity to reach a maximum audience), the ruling elites sought to exploit the advantages of e-diplomacy or digital diplomacy $[1 ; 22 ; 26]$ to talk about public safety, risks and necessary measures, and post-pandemic recovery strategies. Whichever the topic - between the outward-looking blame game (mainly directed against China and the $\mathrm{WHO}$ ) and inward-looking protection of the citizens from the most terrible expectation (through lockdowns, self-isolation, and physical distancing) - the overarching message was that the decisions were taken following planning and thorough consultations, and as such were in the best interest of all, including the state itself, businesses, and people. The obvious discrepancies characterizing responses worldwide provided fertile material for comparisons and, if convenient, a basis used for the sake of superiority narratives; the acknowledgment of one state's good practice did not necessarily translate into its replication elsewhere. By approaching the pandemic as an opportunity and part of future electoral campaign, a good number of administrations - democratic, the socalled hybrid, or fully authoritarian - have cherry picked pieces of advice from their respective health authorities, as well as the severity of measures to be implemented. As the result, we have ended up seeing major discrepancies between different states (as across the US), governments (as in the case of Italy, Sweden, and the UK), or regions (such as the Balkans). Altogether, by placing emphasis on individual popularity and policies least damaging to power continuity, while simultaneously insisting on the negative Other as an obstacle to a solution to the pandemic, both core and peripheral players in the realm of politics and international relations have ultimately demonstrated lack of empathy and solidarity at local (Europe) and global level (UN). More precisely, the initial 'us vs. coronavirus' 
advocacy, which implied a global effort to fight an invisible enemy, was quickly abandoned, providing space for greater flexibility and politization of the question of health emergency. In this new context, the 'us vs. you/them' division was less about the collective handling of the pandemic and much more about intrastate dynamics, including polarization and rising inequalities, with many citizens fearing for their own survival in the so-called new normal.

Given that the covid-19 crisis has been accompanied by all sorts of (un)official assessments, jointly encouraging too many questions and offering too few answers, we seek to shed light on the level and impact of engagement of governments, field experts, and public intellectuals during the pandemic. While policymakers as 'editors-in-chief' have felt passionate about their war metaphors and prompt policies throughout, even when they proved detrimental and likely to cause more damage, the role of field experts and public intellectuals seems to have been limited. Rather than trying to persuade people as to what they should be doing, experts and intellectuals are expected to use their knowledge to provide constructive examination of complex issues and make them accessible, so that the ones who listen to them can hopefully understand the impact of specific policy preferences and minimize their own losses in the increasingly competitive environment. Their status - and luxury to serve as impartial commentators rather than key figures of the political spectrum and decision-making processes — is a matter of both institutional willingness to provide space for their involvement and their own readiness to contribute in a more active manner (individually or by joining other like-minded comrades). While some regimes tend to be more inclined toward a genuine inclusion of experts and intellectuals in debates about system's deficiencies and possible improvements, others tend to show reluctance by treating them as nuisance or trying to limit their access to the public through censorship and promotion of anti-intellectualism. However, whichever the level of expertise or whomever the target of experts, the governments seem to have remained unaffected by them. In fact, in the pursuit of their agendas, they have mainly counted on their own hand-picked advisors. Science and technology have additionally complicated the position of field experts and, in particular, public intellectuals; while providing platforms for dissemination of new ideas and critical thinking, they have also provided algorithms to regulate the suitability of debates on policy alternatives and leadership accountability in a time of emergency.

\section{Government agendas and policy preferences}

Policymakers are individuals involved in formulation, implementation, and amendments to policies many of whom, as a part of the job description, are likely to have the authority to sign off decisions, approve policy documents, and determine allocation of financial resources. For example, in the UK, policymakers include ministers, their advisers, civil servants, officially appointed Chief Scientific Advisers, Parliamentary Committee members, MPs, Lords, and all of their advisory staff. Given their responsibilities and expected commitment to accountability (the extent of which is largely determined by the regime type), policymakers present 
themselves as well-informed and authoritative sources working in the best interest of their respective states and publics. For a successful pursuit of agendas, including new policies, internal coordination and external trustworthiness are key. As explained elsewhere, "public service is a public trust. Citizens expect public servants to serve the public interest with fairness and to manage public resources properly on a daily basis ... Public service ethics are a prerequisite to, and underpin, public trust, and are a keystone of good governance" [52]. The necessity to come across as transparent and trustworthy - a process usually predicated upon wellgrounded ideas and arguments as well as sound solutions to diverse complexities of both national and international relevance - is a modus operandi likely to facilitate preservation of office and thus further consolidation of power.

Looking at the question of problem definition (its analytical and normative dimensions), D. Dery is right to insist on two maxims, that "problems do not exist 'out there,' are not objective entities in their own right, but are analytic constructs, or conceptual entities," and that "definitions of problems in the context of practice must answer the criteria of feasibility and worth, or improvement" $[12 ; 27 ; 33 ; 34]$. With this in mind, the recognition and consideration of problems as part of agenda setting shed light on the very nature of the matter, with some issues being assigned priority status over others. Issues related to poverty, unemployment, or healthcare are a good case in point. While being enough sensitive to affect public opinion and election outcome, they represent convenient policy areas both for the ruling elite and members of the opposition. The officeholders are likely to (ab)use them to confirm their determination to improve the status quo and consequently show off with their achievements (even if minor or significantly smaller in comparison to what was initially promised), whereas for the opposition, the sensitive policy areas are useful for narratives and public appearances aimed at exposure of incompetency and ever increasing discreditation of the ruling elite. This all suggests that policy proposals, including their approval and official application in the form of decisions or procedures, are inseparable from a range of calculations. "Policymakers at least informally make 'political feasibility' assessments", bearing in mind prospects of success, limitations and additional options, threats, and opportunity costs, and immediate as well as long-term consequences [45. P. 111]. In times of unexpected crises, time pressure and availability of relevant data make in-depth examinations much more complicated, with their conclusions being highly speculative or, even worse, grossly inaccurate. In such cases, "those charged with diagnosing political feasibility might benefit from methodological advice that guides an 'armchair' analysis of political feasibility, perhaps relying upon a few phone calls or use of other secondary sources of information" [45. P. 122]. Such an advice proved only partially sufficient at the time of the outbreak and rapid transmission of the novel coronavirus in late 2019. In order to come up with an instant, yet solid, plan and prospective course of action as to how to fight the spread of the pandemic, national policymakers found themselves jumping between messages coming from the WHO and instruments available in their national contexts (decision-making criteria), simultaneously also having to fight an "infodemic" $[67 ; 80]$. In the highly uncertain 
and unpredictable circumstances surrounding the outbreak of the global health crisis, policymakers found themselves under pressure to take strategic decisions that empowered institutions and public servants to impact on the practice of everyday life of ordinary individuals, all the time hoping that their dictates and recommendations would not erode their public standing. To justify or defend their action plans, many opted for a war metaphor.

The metaphor of war is handy. It is used to deconstruct and make complex subjects accessible, and as such, to ensure a sufficient level of attention and public approval so that the fight against the enemy can begin. In the context of covid-19, a war metaphor "may resonate with the public, may help people recognize the threat to public health, may help them take their obligations such as physical distancing seriously. Projection may be a defense mechanism: fears and anxieties are projected into a war with a sub-microscopic enemy, giving a sense of power and control" [30. P. 2]. Moreover, since absolute preparedness is impossible (let alone avoidance of negative consequences), war metaphors help the ruling structures to inflate their leadership capacities, but also shield them from responsibility when things do not go well - war itself implies victims. While the covid-19 crisis and the ad hoc tools such as new mandates, lengthy extraordinary sessions, and frequently modified rules and regulations, have ignored one aspect of the traditional social science approach - the one "attempting to identify the assumptions underlying each policy instrument and to assess their relative costs and benefits, often through the use of fairly abstract mathematical models", they have not ignored the other, largely political, approach, "to formulate the choice of policy largely in terms of which key constituents would lose or gain with different alternatives, how much each alternative is likely to cost, and who would bear that cost. This approach is more representative of what actually happens in the real world, but it is also more ad hoc and idiosyncratic. Consequently, it contributes little to the building of generalizable models of policy implementation" [46. P. 5]. Therefore, the embracement of war metaphors and the elites' consequent handling of the matter insinuate that the global health crisis is actually a political crisis (often fostered and complemented with economic elements), as also confirmed by the official statements calling the virus the "Chinese Virus" [72] or, with the emergence of a new variant in the UK, "British Virus".

In his theory of countervailing responsibility, M. Harmon identifies three types of administrative responsibility - political, professional, and personal and argues that "because various meanings of the word responsibility stand in inevitable tension with one another, it is misleading to equate responsible action in its fullest sense with correct action. Action that is deemed correct from the standpoint of one meaning might very well be incorrect or irresponsible from the standpoint of another" [23. P. 286]. Before proceeding to examine each type's impact on policymaking in close conjunction with covid-19, a number of other dimensions are worthy of mention. For example, the timing and framing of key messages are of utmost relevance, notably when taking place in a moment of great speculations and without any clarity about possible outcomes and repercussions. 
As messages go hand in hand with policy panning, with some ideas as to where the undertaken discussion and subsequent actions should lead, there is a great risk of mistakes and polarization in contexts of unknown or insufficiently researched fields. Policy preferences are sometimes defended with few words and sometimes with more extensive explanations, as to why certain steps are necessary and how they will contribute to the common good: "How well the tasks of government are done affects the quality of the lives of all our people. Moreover, the success of any political leadership in implementing its policies and objectives depends heavily upon the expertise, quality, and commitment of the professional career employees, of government" [38. P. 112]. As part of persuasion tactics, policymakers tend to argue that they have taken into consideration all sorts of things, including previous experiences and conclusions of different consultation rounds, so that they could come up with the best or most appropriate policy. Accordingly, once in place, the ruling elites also rely on the support from civil servants, lobbying networks, and the media.

On the other hand, members of the public tend to associate policies with certain faces, as in the case of the 2010 Affordable Care Act, commonly known as Obamacare, or the 1999 Doctrine of the International Community, commonly known as Blair doctrine (or even before, as in the case of the 1980s economic policies referred to as Reaganomics, or in the case of the 1970s revolution in China referred to as Maoism). This also means that when some of the policies put in place do not work, the public is likely to question and discredit the government in charge of it. Think tanks, independent media, and non-governmental organizations are often at the forefront, aiming to enlighten the public with additional facts, and inviting the ruling elites to take part in an open dialogue about winners and losers of the policies in place. It is in such contexts that, regardless of the arguments presented by the respective policymakers and other stakeholders, altogether insisting that they are working in the best interest of the people, many members of the public start feeling the opposite; more precisely, once they spot features that discriminate against their own interests and well-being, they develop feelings of betrayal and resentment. Aware of the sequence and their government's paralysis to respond with adequate measures, policymakers seek to minimize individual accountability by embracing the collective dimension of (in)action. In the context of covid-19, President Trump stated that "we must sacrifice together because we are all in this together and we'll come through together. It's the invisible enemy. That's always the toughest enemy: the invisible enemy. But we're going to defeat the invisible enemy. I think we're going to do it even faster than we thought. And it will be a complete victory. It'll be a total victory" [7. P. 4]. In a similar, yet more diplomatic, fashion, the importance of togetherness was advertised by UN Secretary-General A. Guterres when declaring that "we are all in this together" [19], and later on, by European Commission President U. Von der Leyen when insisting that "none of us will be safe until everyone is safe" [73]. However, in contrast to key policymakers, some critical non-state actors have been much more reserved about the notion of togetherness. Mindful of economic disparities and substantial 
differences in the death rate between poorer and wealthier areas, they have argued that "just because the UK's prime minister and the Prince of Wales have had covid19 doesn't mean the disease strikes all people equally" [37; 47; 75].

Looking more narrowly at political responsibility — "action that is accountable to or consistent with objectives or standards of conduct mandated by political or hierarchical authority" [23. P. 289] — the sudden nature of the global pandemic exposed a range of discrepancies in government approaches. For example, the EU experienced all sorts of disagreements both in terms of (a) intrastate dynamics (shaped by the type and competency of leadership, the readiness of the healthcare system to confront the pandemic, and the measures adopted in order to protect the well-being of citizens) and (b) interstate relations (either at the bilateral level, through continuous discreditation of each other's strategies and preferences, or at the multilateral level, while expecting the EU to use its supranational powers to assist struggling member states). Yet again, by seeing Dutch and German authorities insult Italian and Spanish responses to the pandemic (as if the two Mediterranean partners wished for socioeconomic complications and international discreditation), the issue of solidarity as a key EU value was widely scrutinized [8; 69]. As also admitted by President Von der Leyen, "when Europe really needed to be there for each other, too many initially looked out for themselves. When Europe really needed an 'all for one' spirit, too many initially gave an 'only for me' response" [57]. In the EU, the dividing polarization accompanying the covid-19 crisis has put even more emphasis on the intergovernmental approach, with national governments seeking to independently identify the most appropriate measures that would consequently help them secure public support and thus preserve the office. Elsewhere, as in the case of Brazil, while continuously downplaying the gravity of the pandemic and expert advice concerning facemasks and physical distancing, President J. Bolsonaro developed a dismissive attitude toward the Chinese government. "Bolsonaro himself repeatedly accused China of being responsible for the pandemic" and described the Chinese vaccine as "untrustworthy' because of its 'origin",, but then felt an aftereffect when it turned out that the main ingredients necessary for Brazil's own vaccine production had to be imported from China proper [16].

By treating the outbreak and handling of the covid-19 crisis as a marketing strategy for the sake of power maximization, various members of the ruling elites worldwide carefully selected what advice and measures to pursue so they would have the least adverse impact on their popularity (in fact, President Bolsonaro got rid of two health ministers because of their noncompliance). Under the circumstances, somewhere on the (in)competence scale, the metaphor of war appeared as a convenient policy instrument. "The declaration of the war on covid19 occurred during the time of record-setting economic indicators (including lower unemployment in the USA, higher New York Stock Exchange closing figures and the international trade negotiations); however, the social and political climate of the nation after the first case of coronavirus became anxious, exhausted and angry ...Health-related challenges from the virus, a severe economic downturn, localized 
food shortages, quarantines and lockdowns, all racially charged civil unrest, and social unrest related to citizen's rights" [10. P. 1115]. While in the view of policymakers around the world, a war metaphor was imagined as capable of bolstering togetherness, in the view of many citizens, it was actually a tool used to silence discontent and send a message that whoever was opposed to it, they were actually against the ruling elite and their efforts to fight the invisible enemy. Moreover, the call to unite around a common purpose lost its significance as soon as it became clear that equal commitment did not imply less discrimination but further erosion of the position of most vulnerable groups. With this in mind, while they were not necessarily against the elites' war metaphors when they implied "an 'all-in-this-together' mentality, unifying the public behind their health heroes, lauding their courage and emphasizing the need for essential funding and adequate personal protective equipment for health workers", they did start to dispute them when it turned out that the ruling structures were failing to provide necessary protection: "In a war, heroes get medals, but deserters are shot, so are those vulnerable healthcare workers who feel unable to work on the frontline and request redeployment also 'deserters'? Healthcare workers may arguably have accepted a slightly higher risk to themselves by pursuing their vocation. While they have a duty to care for patients, they have no obligation to sacrifice themselves" [30. P. 2; 43. P. 624, 625].

Furthermore, during the pandemic, the question of public health increasingly became a matter of securitization. With the constant reporting of mortality rates as significantly higher than those caused by influenza, the rules and regulations accompanying the proclamation of war against coronavirus as an existential threat also served to prevent collapse of healthcare systems. One study has looked at the situation in Hungary, outlining how the state of emergency resulted in the expansion of powers that "allowed the government to rule by decree for an indefinite period of time;" the arrival of the pandemic meant limited movement and interaction of people, and thus implied closure of shops, companies, and different institutions, with "military and police commanders dispatched to hospitals to supervise the implementation of emergency measures and later to institutions of strategic importance" [49. P. 1169]. So, the identification of four securitization prerequisites agent, threat, object, and audience [76] — provided a platform of greater control, with power being kept in the hands of a very small group of people. Moreover, and in contrast to visible enemies, the invisible and, equally important, global nature of covid-19, as well as the concomitant speculations about its origin and handling strategies, provided the executives with a higher degree of flexibility in terms of policy preferences and subsequent accountability repercussions. It is for this reason, conveniently accommodated in the discourse about public health and desire to save lives, that the question of blame (aggressor) has not received major attention by the ruling authorities around the world; in fact, those who decided to engage with it, have experienced disapproval and widespread criticism.

In terms of dilemmas surrounding professional responsibility - "action that is informed by professional expertise, standards of ethical conduct, and by experience 
rooted in agency history and traditions" [23. P. 289] — the fact that different executives opted for measures diametrically opposed to one another in order to deal with the covid-19 health crisis, yet all of them insisting that their approach was in the best interest of their fellow citizens, created a major confusion in terms of trust and (in)competence. While there is no doubt that governments found themselves in gray areas and having to perform multiple actions and responsibilities as well as to consider information of complex and rather ambiguous character, members of the public were primarily concerned with the ruling elites' honesty, impartiality, and capacity to work in the public interest. In her attempt to understand why the outbreak and handling of the pandemic necessitated metaphorical connotations, E. Semino rightly concluded that "metaphor involves talking and, potentially, thinking, about one thing in terms of another, where the two things are different, but some similarities or correspondences can be perceived between them. For example, when B. Johnson talks about a 'fight' in his statement from March 17 2020, he talks about the attempt to reduce infection, illness, and death from the new coronavirus in terms of a violent physical confrontation with an opponent. The two things are obviously different, but we can perceive similarities between them. For example, both are difficult and dangerous enterprises that require effort and concentration, and both involve harm to people, and, in some cases, death" [63. P. 50].

What we imagine here is also a close relationship between the executive and a number of policy advisors, who, depending on their own position and integrity, can play a key role in policy processes. While based behind the scenes, depending on the executive's readiness to take them seriously and allow for their intervention even when it is in complete contrast with some predetermined preferences and rights, they will seek to invest efforts in the development of new arguments and policy alternatives. Accordingly, some policy advisors, inspired by the expected level of professionalism, will feel free to openly discuss problems while simultaneously offering solutions, whereas others would side with the government and in fact help it to consolidate its position, no matter how detrimental the impact of its policies might be. "Regardless of what indicator data may suggest about a particular policy problem, policymakers prefer policy instruments consistent with their own values... However, few policymakers act alone or without constraints that limit their range of choice. Consequently, the selection of a policy instrument depends on a policymaker's constraint and the resources available either to diminish the force of those constraints or to enhance the effectiveness of a given instrument. Resources and constraints thus determine what is feasible" [46. P. 21].

In any case, including instances that require large-scale collective action, it is a very small number of policy advisors who appear publicly and share what they are exactly doing and how they shape policies and government behavior. Needless to say, with different regimes implying different levels of creativity and freedom of expression of those populating inner circles around those in executive positions, it does not make much sense to expect substantial coherence among heterogeneous actors and their approaches. Moreover, and again closely related to the problem of large-scale collective action, even if coordinated at a global level - as in the case 
of curfew and other restrictions, such as school closures - there have been obvious variations in the handling of the covid-19 crisis, since unattractive rules and regulations can erode the popularity of the government. This is especially the case when measures disproportionately target and thus affect the income of poorer communities. "It can be costly for parents to stay home with their sick children, as they might risk losing their jobs; therefore, parents may send their children to school even when they have mild symptoms and, furthermore, even if the parents know their children might spread the virus" [24].

Being professional also means trustworthy. With this in mind, the sound war metaphors, communicated by the executives (and never publicly challenged, let alone discarded and abandoned, by any of their policy advisors), served to consolidate governments' overall standing, which corresponds to professional preparedness. With the outbreak of the pandemic, since governments were unwilling to collapse in front of the so-called invisible enemy, war metaphors helped to neutralize public skepticism and render low trust in government less relevant - in the end, it was an emergency and who else was supposed to take care of it except those holding the office. As clarified elsewhere, "the regulations and recommendations will have no effect if the citizens abstain from complying. If the authorities do not trust the citizens and people do not trust each other, countries have to rely on hard monitoring and enforcement of regulations (e.g., armed forces enforcing the curfew)... Citizens must trust that the recommendations they receive from the public authorities are correct, that these are in their (or the collective's) best interest, and that most others will follow the recommendations" [24]. In contrast to times of peace, when the public is more prone to expressing low trust in the government, during the global health crisis (in particular, its early stage) and introduction of restrictive measures worldwide, many have shifted their focus, paying much more attention to health, job security, and family well-being, than to the necessity, appropriateness, and quality of the imposed restrictions, often referred to as the new normal.

Finally, with regard to personal responsibility - "action that is informed by self-reflexive understanding; and emerges from a context of authentic relationships wherein personal commitments are regarded as valid bases for moral action" [23. P. 289] — the covid-19 crisis stressed the power of individual experiences in the context of policy preferences. With this in mind, the fact that some key policymakers caught the virus and had to be hospitalized themselves served as a confirmation that everyone was in the same boat (in terms of risk, not treatment), but, even more importantly, as an incentive to defend or reconsider the previously embraced partiality about the handling of the pandemic. Therefore, while insisting on personal experiences as a part of their open-mindedness toward policy alternatives (with least detrimental effects), and while at some point having to fight for their own life as well as to continue fighting the invisible enemy on behalf of their fellow citizens, policymakers sought to spread a message according to which, a fighter mentality was a prerequisite for successful handling of the given situation: "The representation of, for example, populist leaders such as B. Johnson 
and D. Trump as too strong to be beaten by the virus can indeed reinforce the perception that recovery depends on character, rather than a combination of demographic characteristics, genetics, circumstances, and medical treatment" [63. P. 52]. However, on the other hand, such messages managed to stress and further deepen the 'us vs. you/them' division, presenting policymakers as more mature and somewhat superior to the rest of the society. Such an approach usually results in stigmatization, with effects of infantilization: "One is led to believe that the population as a whole is unable to comply with the rules and that there are particular groups that do not have this ability. This can lead to discriminatory behavior, including ableism, ageism, classism up to actual racism" [5]. In fact, many members of the public have experienced confusion and misunderstanding as to who was to be fought, the novel coronavirus or other members of the society (especially the ones not willing to follow the rules and regulations).

The access to variety of information channels, with social networks at the forefront, also provided policymakers with an opportunity to immediately communicate their own experiences to wider audiences, using the timely interaction as an expression of commitment to the well-being of others. Research has shown that "evoking war scenarios to talk about pandemic increases the level of emotional involvement, and this strategy becomes more effective on those participants who are more interested in high level of arousals, such as those who use independent information channels and social networks... These individuals will be more susceptible to accept also the other bellicose entailments that are evoked by the war metaphor" [53. P. 27]. Thus, the readiness of the public to embrace the narrative presented by policymakers - for as long as the minimum level of trust persists, which is also maintained by occasional involvement of different pro-government non-state actors - explains public vulnerability to the metaphorical representation of the state of affairs. As it turned out, it was primarily field experts and public intellectuals who have spent time trying to distinguish between different responsibilities and the risk of causing harm in the war against the invisible coronavirus enemy. In fact, in order to show the gravity and detrimental impact of war metaphors, some authors go as far as to link their appeal to the question of cancer: "It is much simpler to discuss taking potentially toxic chemotherapy to ward off an anthropomorphized evil entity, for example, than to delve into the nuances of unintended treatment toxicities and prognostic uncertainty. Metaphors may help personalize discussions and broach topics such as end-of-life care that might otherwise be difficult to initiate" [43. P. 624, 625]. With the vision of winning, which implies that the winner is better equipped (ammunition or body health), pressure tends to increase, which also implies readiness to accept exploration and introduction of new methods and additional measures (war strategy or medical therapy), to gain advantage and secure (auto-)destruction of the Other.

\section{Field experts between profession and public expectations}

Governments rely on field experts - generally defined as professionals with a thorough, science-based, understanding of a particular matter — to provide input 
during different stages of the policy process $[33 ; 51 ; 56]$. They are usually recognized as people who have invested a lot of time and effort in knowledge acquisition so that their findings and recommendations, together with familiarity with other contexts and sound comparative perspectives, are difficult to dispute. In addition, "scientists can take on the role of both neutral experts and strategic policymakers. Scientists not only serve as sources of information, but can act as full coalition members and strategic actors with their own belief systems congruent with the coalitions of which they are members" [29. P. 1010]. Such a view, in combination with the different types of regimes, also suggests that depending on circumstances, certain experts will not exclude the option of self-censorship for as long as they see a good reason for it (in many instances, compensation and prospects for future engagement). In contrast to fully democratic environments, (semi-) authoritarian governments tend to select their experts on criteria that are often unrelated to the role requirements; they are expected to provide legitimacy for the ruling elite's policy preferences rather than insist on alternatives that could potentially threaten the leadership. Here, knowledge is used for the purpose of coverup and not to evaluate or challenge the status quo. In fact, insisting on their knowledge and professional experience may cost experts their position. Alongside this thinking, many of them end up limiting their involvement by staying on the periphery of main discussions - a decision seen as contributing to gradual erosion of their professional recognition.

"The role science plays can then also impact upon how evidence and knowledge provided by scientists is used by decision-makers and other subsystem actors," and "the use of knowledge and the roles that scientists play impacts on the degree of adverseness within the subsystem" [29. P. 1011]. Moreover, someone sitting at the moment of the outbreak of covid-19 pandemic in Moscow and Washington and respectively advising the Russian and American administrations, could have easily found themselves inadequately prepared to address the dilemma about the handling of the novel coronavirus. Initially, they relied on research data shared by the hotspot (Wuhan-based labs and markets) and stories prepared by a handful of reporters who happened to be in China at the time. Thus, we need to distinguish between experts and researchers, with the former category being the one that needs the latter's primary sources. While ready to commit themselves to examination of new or insufficiently explored areas, researchers use their training to investigate their subject from different angles. Accordingly, they are interested in cultural perspectives, official discourses reflecting the political climate, and the socioeconomic position of polity members. Therefore, experts' claims about the situation in a remote context, such as that of the city of Wuhan at the very beginning of the global health crisis, can also be discredited as pure speculation if not properly supported by cross-checked data. Thinking about the likelihood of research influencing policy development, some authors observe that policy recommendations often represent "the most difficult part of the project", since "neither the researchers nor the participants are particularly well placed to make informed judgments about the best responses to the evidence presented" [71. P. 40]. 
With this in mind all the advocacy, with the WHO at the forefront, calling for the closure of wet markets [40; 50], was nothing more but an expression of frustration and initial guesstimate about the origin of coronavirus, which gradually started to disappear, so much that by the end of 2020 any mention of such markets (open and fully operational) and their exotic animals had fully vanished.

When researchers find themselves in an environment characterized by strict controls regulating access to information, it is likely that their attempts to examine controversial issues will face obstacles, leaving their findings incomplete or, even worse, inaccurate: "Specific answers to specific questions cannot be guaranteed, nor is there any certainty that evidence to support or counter a particular policy move will be generated" [71. P. 41]. Some former studies have shown that although policymakers tend to acknowledge the importance of academia, a very large majority of them "preferred to work with researchers who had a solid understanding of government that included a knowledge of public health infrastructure, bureaucracy and parliamentary processes, and the social-political history of policy reform", believing that a solid grasp of politics is a prerequisite for substantial engagement with policy processes, their development and timely modifications [25. P. 5]. Moreover, such a combination is seen as more attractive and reassuring in front of the public - a strategic move that also increases the overall credibility of policymakers. As reported, they do not appreciate "researchers who "came out with guns blazing"" and "made "wild claims or wild predictions", or "researchers" 'unrealistic expectations' about government process, and a failure to appreciate the 'big, complex picture in which [policymakers] work'" [25. P. 5]. Finally, and this is surely key, policymakers are obsessed with confidentiality and perceive a researcher's interaction with the media as potentially dangerous. In policymakers' words, "'anybody that is likely to be trouble,' or may be 'difficult to control,' who might 'go to a press conference and launch an attack on the government' — was excluded from insider conversations", and while they recognized "researchers' 'democratic right' to criticize government policy", no policymaker was in favor of "the role of researchers in holding governments accountable" [25. P. 6].

In order to further unpack and facilitate understanding of the above dynamics (including possible side effects), another analysis of the role of research in policy formulation has identified the following factors as key: "(i) timing; (ii) identity of the researcher; (iii) the involvement of researchers in policymaking positions; (iv) communication; (v) perceptions of usefulness; (vi) good relationship between researchers and policymakers; (vii) political feasibility; and (viii) political legitimacy" [17. P. 570]. Consideration of these factors is likely to shed light on what can go wrong and on the overall complexity of working relationships. However, in case of unexpected and large-scale catastrophes, which require immediate reaction and treatment, the pressure does not allow for too much deliberation, calls for expression of interests, or muttering about mandates and their legal provision.

The sudden nature of covid-19 exposed insensitivity to the issue of timing, with a number of governments consequently accused of their "too little, too late" 
approach [4; 54]. More precisely, although researchers have sought to provide timely advice to prevent the spread of pandemic, some authorities decided to ignore it; for example, the British government did not follow the safety guidelines and lockdown recommendations provided by the Scientific Advisory Group on Emergencies even though they argued that the country was facing a "very large epidemic with catastrophic consequences" [61]. In its defense, the government rightly stressed that even the researchers themselves differed in their opinion $[11 ; 20]$, which somehow served to suggest that the ministers felt flexible and thus opted to balance between the protection of lives and the National Health Service, on the one hand, and education and job security by keeping people in employment, on the other [74]. Admittedly, such an approach is not a novelty. "While researchers are trying to find answers to an academic question, a policymaker is trying to solve a problem which sometimes is time-sensitive. So, you may need to move without the luxury, privilege, advantage of firm information. And you need to make the judgment [between what] you need to know and when you are willing to take a risk" [28. P. 75; 68].

The decision to downplay researchers and the obvious discrepancies concerning research findings but also those between researchers and policymakers, left the public highly perplexed, if not in a state of permanent confusion. For the public, especially its members interested in comparative perspectives and developments across the national border, seeing other states perform much better than their own is an indication of an absence of strategic thinking at home. Looking at the triangle encompassing researchers, field experts and policymakers, with the public having interest in each of them (but not necessarily the other way around), studies have already established that communication and open dialogue are of utmost importance. "The communication of science to policymakers is recognized as an important site for the construction of the meanings of scientific uncertainty in society, but it is not the only one. Another site is the media, which play a critical role for the dissemination of scientific knowledge in society" [36. P. 280; 9]. However, from the very beginning, the covid-19 crisis was accompanied by reports loaded with speculation and contrasting interpretations and as such incentivized politization of the matter and greater polarization of the public. In fact, the more the global health absorbed elements of (geo)political confrontation, the lesser the relevance of research findings of both national and international nature seemed to be. "The minister is the one who sets the vision. Then the political agenda is discussed within the advisory committees of all departments", and, perhaps more significantly here, "it is national leadership... that retains a key role in taking responsibility for the way the policy is formulated and the extent to which research plays a role in policymaking" [28. P. 76].

In contrast to policymakers for whom the metaphor of war seemed convenient, other experts spent much more time thinking about it. For example, in June 2020, the independent and multidisciplinary World Emergency covid-19 Pandemic Ethics Committee offered a number of recommendations calling for a reconsideration of the use of war metaphors [5]. The committee argued that such a preference among 
key policymakers is "extremely dangerous because it risks transforming preventive public health procedures into instruments of social control", given that war emergencies imply mobilizations and brutal killings to combat the enemy. On the other hand, fighting the spread of coronavirus has not implied killings of people, but protection of all, including others from ourselves, as evidenced through physical distancing and wearing of facemasks. While this confusion and obvious difference are clear to some, others, especially children and adolescents (and particularly those immersed in warlike videogames) may take a different view while hearing that the environment they are growing in is full of fear and at war of global proportions. Furthermore, the committee stressed the absolute need "to avoid any form of stigmatization toward those who do not respect the health rules", but instead called the relevant authorities to enlighten them so they would become savvier about safety measures, including their duration.

However, the call to reconcile the 'us vs. them (enemies)' difference was easier said than implemented given the number of key political figures who themselves mocked the value of individual responsibility, rejecting to wear a facemask and maintain physical distance [59]. By sending messages that masks were useless and did not threaten (their) health, they directly provided support to groups opposing face covering - a highly polarizing trend that transformed the question of mask and health into a cultural and political divide; as in the US case, "for progressives, masks have become a sign that you take the pandemic seriously and are willing to make a personal sacrifice to save lives. Prominent people who don't wear them are shamed and dragged on Twitter by lefty accounts. On the right, where the mask is often seen as the symbol of a purported overreaction to the coronavirus, mask promotion is a target of ridicule, a sign that in a deeply polarized America almost anything can be politicized and turned into a token of tribal affiliation" [39]. Finally, the Committee recommended replacing the metaphor of war with the term resistance. However, in contrast to warlike contexts and course of action in order to win the war even though victory may not be the final outcome, resistance strategies tend to be more flexible throughout due to their fluctuating nature between exaggerated activity and passivity. As such, while they are capable of shedding a better light on warlike propagandistic rhetoric, they may also come across as confusing and potentially more damaging in the eyes of the masses nervously waiting for a solution.

\section{The limited role of public intellectuals}

The outbreak of covid-19 and consequent response by international organizations and different governments inspired many intellectuals to comment on the state of affairs. While some of them have rightly argued that the handling of the pandemic exposed "another colossal failure of the neoliberal version of capitalism" [41], and that "more than open barbarism [they] fear barbarism with a human face — ruthless survivalist measures enforced with regret and even sympathy, but legitimized by expert opinions" [81], some others went on to warn the audiences that the measures put in place (for example, in Italy) were "irrational and entirely unfounded", used 
by governments to paralyze countries and limit our freedom "in the name of a desire for safety that was created by the same governments that are now intervening to satisfy it" $[2 ; 3]$. Thus, the debate is about intensification of oppression imposed by the system (the ruling political and economic elites) on the already tired polity, often referred to as the precariat or the burnout society. As warned some time ago, the precariat, while experiencing the so-called four A's - "anger, anomie, anxiety, and alienation" - is bound by "short-termism, which could evolve into a mass incapacity to think long term, induced by the low probability of personal progress or building a career" [66. P. 31,33]. On the other hand, the burnout society is concerned with "the achievement-subject that competes with itself... in the destructive compulsion to outdo itself over and over"; in this race, life is reduced to "the illusion that more capital produces more life, which means a greater capacity for living... Concern about living the good life yields to the hysteria of surviving" [21. P. 46, 50].

While the portrayal of precariat and burnout society corresponds to the widening gap in income inequality between the rich and the poor, both categories, however, are obsessed with individualism. Moreover, the obsession with temporary opportunism due to fear about the future (robotics and automation), makes any discussion about sustainability or sustainable development look like an abstract wishful thinking. Competition and compensation as per the current system leave no room for collectivism; in fact, collectivism is seen as an obstacle to progress and accumulation. Trade unions are perceived as a leftist nuisance and the work of NGOs is silenced by the establishment of government-organized non-governmental organizations (GONGOs). Accordingly, the pandemic has been used to justify implementation of emergency measures, some of which threaten the rule of law and civil liberties: "if passed quickly by parliament in the context of the emergency, the new legislation, once entered into force, will be applicable even after the end of the pandemic. Decrees issued during the state of emergency — including the practice of detaining journalists for their work and the abuse of pre-trial detention and internet censorship - may become permanent measures used to restrict freedom of expression and freedom of the media, and to shout down dissenting voices" [44. P. 167, 168]. The severity of this warning is even more alarming when juxtaposed with the policy goals in relation to internet freedom and information management, as prescribed by digital diplomacy objectives; while the former implies "objectives of promoting freedom of speech and democracy as well as undermining authoritarian regimes," the latter is supposed amass information in order "to better inform policymaking and to help anticipate and respond to emerging social and political movements" $[6 ; 22 ; 55]$.

With this in mind, the invisible enemy covid-19 has additionally exposed the system's fragility and proneness to illiberal or even fully authoritarian practices, and with this in mind, the embracement of war metaphors by different regimes makes perfect sense. The equation between health and war (with all its accompanying rules and regulations) as a precondition of survival has imposed the requirement to sacrifice freedom and be ready for a new wave of isolation and self- 
censorship. The use of warlike terminology (death, enemy, and confrontation) as a substitute for terminology associated with healthcare emergency (life, empathy, and solidarity) is a way of securing legitimacy for any future emergency and its "effects on social behavior", as well as "effects on political climate and democratic values" [60. P. 619, 620].

The restrictions have the potential to limit the involvement of public intellectuals as critically endangered species seeking to share ideas about trends in place and possible future scenarios. As witnessed on numerous occasions in the past, the blurred line between acceptable and unacceptable evaluation of the handling of emergencies can easily result in labeling with detrimental consequences. Back in 2011, the American Association of University Professors recalled its nearly century-old founding documents, suggesting that "the mission of universities and colleges included not only research into or teaching of new ideas and providing experts to serve the community but also the teaching, interpretation, and communication of long-standing intellectual and artistic works and values. Further, for academics to contribute their ideas freely to the larger society, the 1915 declaration emphasized that academic extramural expression, in addition to academic work, should be protected under principles of academic freedom" [13. P. 2]. However, as the result of the covid-19 lockdown, institutions of higher education had to close their campuses and the whole environment became virtual within a matter of days [42], without proper interaction, and thus learning and knowledge accumulation, all key for democratic decision-making [14]. In contrast to a packed classroom or conference room, difficult to leave when unpleasant yet highly relevant discussions take place, the new setting has offered a quick fix, instead - the mute button. While few realize the real power behind platforms offering such an option - sociocultural (self)exclusion or (self-)estrangement - others have welcomed them as a non plus ultra solution to their academic needs. More alarming than the (mutual) muting privilege is the censorship prerogative, with major web channels and social media being in a position to filter narratives by deciding what is acceptable or whose account should be canceled. Going forward, depending on their ideas and arguments, be it about freedom, leadership, or (anti-) vaccination, the presence of public intellectuals, like anybody else's except those in charge, is likely to be monitored and, depending on the level of controversy, sanctioned.

The new normal, widely advertised as a byproduct of the pandemic, has taken governments, field experts, and public intellectuals by surprise. The consequent frustration, largely due to the uncertainty and constant need to predict the nature and next steps of the invisible enemy, has encouraged questions about the system we tend to argue we understand. However, "there has never been so much knowledge about our ignorance and about the compulsion to act and live under uncertainty" [32]. We have spotted uncertainty when observing the behavior of the ruling elites, of researchers and field experts fighting whose opinions should count and whose should be discarded, and of public intellectuals who have traditionally 
sought to expose malfunctions and propose alternatives, but whose voices and registers often remain unheard by wider audiences. Moreover, dissatisfactions of one of the three groups with other two and the need for mutual undermining for the sake of personal gain and influence maximization, can also been interpreted as an absurdity in the context of growing inequalities and the more voluminous precariat. The new normal has also encouraged questions about the power of institutions, at both national and international levels. Half a century ago, one study stressed that "whatever else organizations may be (problem-solving instruments, sociotechnical systems, reward systems, and so on), they are political structures. This means that organizations operate by distributing authority and setting a stage for the exercise of power" [79. P. 1; 78]. And later on, in the early 1990s, playwright S. Tesich warned us of our own selves: "We are rapidly becoming prototypes of a people that totalitarian monsters could only drool about in their dreams... We have freely decided that we want to live in some post-truth world" $[35 ; 64 ; 70]$.

What covid-19 has clarified, and potentially incentivized a need for speedy reconsiderations, is that in front of emergencies, none of these values seem to matter, and regardless of the level of (il)liberalness of regime in place, governments are ready to implement measures that directly affect civil liberties. With all the speculation about the origin of the invisible enemy and volatility in terms of policies expected to reduce mortality rates, they still managed to get away with more surveillance and less accountability. This also sends a sound message to a whole range of non-state actors, including experts, media outlets, and public intellectuals. Correspondingly, the whole talk about the new normal is a trap, which should be rejected. The contractual relationship across circles of policymakers and tacit approval of questionable policies is not only a matter of state capture (power maximization and wealth accumulation), but of morality as well - those who consciously embark on it and those who, equally cognizant, tolerate it. Luckily, the covid-19 crisis has from the very beginning inspired writings looking at the very question of ethics $[15 ; 31 ; 58 ; 62]$. With this in mind, coupled with the growing pressure coming from the ruling structures, the covid-19 emergency is an open invitation for protest and resistance (some of which already promoted by the movements Black Lives Matter, Extinction Rebellion, and Yellow Vests), and therefore it could be treated as a welcome introduction to a new (ab)normal, with alterations in the rules or responsibilities, in order to ensure less uncertainty and more accountability.

\section{Funding}

Carlos González-Villa receives funding from the European Regional Development Fund (No. 2020/3771).

\section{References}

[1] Adesina O.S., Summers J. Foreign policy in an era of digital diplomacy. Cogent Social Sciences. 2017; 3 (1).

[2] Agamben G. Chiarimenti. Quodlibet. 2020, March 17. 
[3] Agamben G. L'invenzione di un'epidemia. Quodlibet. 2020, February 26.

[4] Altman D. Understanding the US failure on coronavirus. BMJ. 2020, September 14.

[5] Arawi T., Chakraborty R., Cutter A.M., et al. A call to cease the use of war metaphors in the covid-19 pandemic. URL: https://www.researchgate.net/publication/342232798_A_Call_ to_Cease_the_Use_of_War_Metaphors_in_the_COVID-19_pandemic

[6] Barrinha A., Renard T. Cyber-diplomacy: The making of an international society in the digital age. Global Affairs. 2017; 3 (4-5).

[7] Bates B.R. The (in)appropriateness of the war metaphor in response to SARS-CoV-2: A rapid analysis of Donald J. Trump's rhetoric. Frontiers in Communication. 2020; 5.

[8] Bertoncini Y. European solidarity in times of crisis: A legacy to be deepened in the face of covid-19. URL: https://www.robert-schuman.eu/en/european-issues/0555-european-solidarityin-times-of-crisis-a-legacy-to-be-deepened-in-the-face-of-covid-19.

[9] Besley J.C., Nisbet M. How scientists view the public, the media and the political process. Public Understanding of Science. 2013; 22 (6).

[10] Chapman C.M., Miller D.S. From metaphor to militarized response: The social implications of "we are at war with covid-19" crisis, disasters, and pandemics yet to come. International Journal of Sociology and Social Policy. 2020; 40.

[11] Costello A. The government's secret science group has a shocking lack of expertise. Guardian. 2020, April 27.

[12] Dery D. Agenda setting and problem definition. Policy Studies Journal. 2000; 21 (1).

[13] Ensuring academic freedom in politically controversial academic personnel decisions. URL: https://www.aaupunion.org/NR/rdonlyres/895B2C30-29F6-4A88-80B9-FCC4D23CF28B/ 0/PoliticallyControversialDecisionsreport.pdf.

[14] Eschenbacher S., Fleming T. Transformative dimensions of lifelong learning: Mezirow, Rorty and covid-19. International Review of Education. 2020; 66.

[15] Ethics and covid-19. URL: https://www.who.int/teams/health-ethics-governance/diseases/ covid-19.

[16] Garcia RT. Brazil's COVID-19 catastrophe: Nothing less than criminal. Aljazeera. 2021, February 1.

[17] Gordon-Strachan G., Bailey W., Lalta S., et al. Linking researchers and policy-makers: Some challenges and approaches. Cad Saúde Pública. 2006; 22.

[18] Greenfield P. Ban wildlife markets to avert pandemics, says UN biodiversity chief. Guardian. 2020, April 6.

[19] Guterres A. We are all in this together: Human rights and covid-19 response and recovery. URL: http://webtv.un.org/watch/player/6151599935001.

[20] Hamzelou J. UK's scientific advice on coronavirus is a cause for concern. New Scientist. 2020, March 23.

[21] Han B-C. The Burnout Society. Stanford; 2015.

[22] Hanson F. Baked in and wired: E-Diplomacy@State. Brookings Foreign Policy Paper Series. 2012, October 25.

[23] Harmon M.M. The responsible actor as 'tortured soul:' The case of Horatio Hornblower. Administration and Society. 1989; 21 (3).

[24] Harring N., Jagers S.C., Löfgren Å. Covid-19: Large-scale collective action, government intervention, and the importance of trust. URL: https://doi.org/10.1016/j.worlddev.2020.105236.

[25] Haynes A.S., Derrick G.E., Redman S., et al. Identifying trustworthy experts: How do policymakers find and assess public health researchers worth consulting or collaborating with? PLoS One. 2012; 7 (3).

[26] Hocking B., Melissen J. Diplomacy in the Digital Age. Hague; 2015.

[27] Hogan J., Howlett M. (Ed.). Policy Paradigms in Theory and Practice: Discourses, Ideas and Anomalies in Public Policy Dynamics. Basingstoke; 2015. 
[28] Hyder A.A., Corluka A., Winch P.J., et al. National policy-makers speak out: Are researchers giving them what they need? Health Policy and Planning. 2011; 26 (1).

[29] Ingold K., Gschwend M. Science in policy-making: Neutral experts or strategic policymakers? West European Politics. 2014; 37 (5).

[30] Isaacs D., Priesz A. Covid-19 and the metaphor of war. Journal of Paediatrics and Child Health. 2020; 57 (1).

[31] Jamrozik E., Selgelid M.J. Covid-19 human challenge studies: Ethical issues. URL: https://doi.org/10.1016/S1473-3099(20)30438-2.

[32] Jürgen Habermas über Corona: "So viel Wissen über unser Nichtwissen gab es noch nie." Frankfurter Rundschau. 2020, April 10.

[33] Kingdon J.W. Agendas, Alternatives and Public Policies. London; 2013.

[34] Knoepfel P., Larrue C., Varone F., et al. Public Policy Analysis. Bristol; 2011.

[35] Krasni J. How to hijack a discourse? Reflections on the concepts of post-truth and fake news. URL: https://www.nature.com/articles/s41599-020-0527-z.

[36] Landström C., Hauxwell-Baldwin R., Lorenzoni I., et al. The (mis)understanding of scientific uncertainty? How experts view policy-makers, the media and publics. Science and Culture. $2015 ; 24(3)$.

[37] Laurencin C.T., McClinton A. The covid-19 pandemic: A call to action to identify and address racial and ethnic disparities. Journal of Racial and Ethnic Health Disparities. $2020 ; 7$.

[38] Lewis C.W., Gilman S.C. The Ethics Challenge in Public Service: A Problem-Solving Guide. San Francisco; 2005.

[39] Lizza R., Lippman D. Wearing a mask is for smug liberals. Refusing to is for reckless Republicans. Politico. 2020, May 1.

[40] Lynteris C., Fearnely L. Why shutting down Chinese 'wet markets' could be a terrible mistake. Conversation. 2020, January 31.

[41] Magdaleno C. Chomsky on covid-19: The latest massive failure of neoliberalism. EURACTIV. 2020, April 25.

[42] Marinoni G., van't Land H., Jensen T. The impact of covid-19 on higher education around the world. URL: https://www.unibasq.eus/wp-content/uploads/2020/06/iau_covid19_and_ he_survey_report_final_may_2020.pdf.

[43] Marron J.M., Dizon D. $\bar{S}$., Symington B., et al. Waging war on war metaphors in cancer and covid-19. JCO Oncology Practice. 2020; 16 (10).

[44] Marsili M. Covid-19 infodemic: Fake news, real censorship information and freedom of expression in time of coronavirus. Europea. 2020; 5 (2).

[45] May P.J. Politics and policy analysis. Political Science Quarterly. 1986; 101 (1).

[46] McDonnel L.M., Elmore R.F. Alternative Policy Instruments. Santa Monica; 1987.

[47] McGreal C. The inequality virus: How the pandemic hit America's poorest. Guardian. 2020, April 9.

[48] Merkel: Coronavirus is Germany's greatest challenge since World War II. Deutsche Welle. 2020, March 18.

[49] Molnár A., Takács L., Harnos E.J. Securitization of the covid-19 pandemic by metaphoric discourse during the state of emergency in Hungary. International Journal of Sociology and Social Policy. 2020; 40.

[50] Ng K. Coronavirus: WHO urges China to close 'dangerous' wet market as stalls in Wuhan begin to reopen. Independent. 2020, April 13.

[51] Nicholson-Crotty S. Bureaucratic competition in the policy process. Policy Studies Journal. 2005; 33 (3).

[52] OECD. Building public trust: Ethics measures in OECD countries. URL: http://www.oecd.org/ mena/governance/ 35527481.pdf. 
[53] Panzeri F., Di Paola S,. Domaneschi F. Does the covid-19 war metaphor influence reasoning? Socio-political factors mediate the framing effect. URL: https://psyarxiv.com/q5d48.

[54] Perrigo B. Coronavirus could hit the UK harder than any other European country: Here's what went wrong. Time. 2020, April 7.

[55] Potter E.H. (Ed.). Cyber-Diplomacy: Managing Foreign Policy in the Twenty-First Century. Montreal; 2002.

[56] Putnam R. The Comparative Study of Political Elites. Englewood Cliffs; 1976.

[57] Rios B. Commission chief, MEPs slam lack of EU solidarity in covid-19 crisis. EURACTIV. 2020, March 26.

[58] Robert R., Kentish-Barnes N., Boyer A., et al. Ethical dilemmas due to the covid-19 pandemic. Annals of Intensive Care. 2020; 10.

[59] Roberts W. Donald Trump repeatedly refused to wear a mask and mocked Biden. Aljazeera. 2020, October 2.

[60] Sabucedo J.-M., Alzate M., Hur D. Covid-19 and the metaphor of war. International Journal of Social Psychology. 2020; 35 (3).

[61] Sample I. Covid: Ministers ignored Sage advice to impose lockdown or face catastrophe. Guardian. 2020, October 13.

[62] Schwartz MC. The Ethics of Pandemics. Peterborough; 2020.

[63] Semino E. "Not soldiers but fire-fighters" - metaphors and covid-19. Health Communication. 2021; $36(1)$.

[64] Shelton T. A post-truth pandemic? Big Data \& Society. 2020; 7 (2).

[65] Smith G. Is covid-19 nature's revenge? Berkeley Daily Planet. 2020, March 15.

[66] Standing G. The Precariat: The New Dangerous Class. London; 2014.

[67] Stephens M. A geospatial infodemic: Mapping Twitter conspiracy theories of covid-19. Dialogues in Human Geography. 2020; 10 (2).

[68] Sterling A., Gee D. Science, precaution and practice. Public Health Reports. 2002; 117 (6).

[69] Stevis-Gridneff M. As Europe confronts the coronavirus, what shape will solidarity take? New York Times. 2020, April 8.

[70] Tesich S. A government of lies. Nation. 1992, January 6.

[71] Thomas W., Hollinrake S. Policy-makers, researchers and service users: Resolving the tensions and dilemmas of working together. Innovation. 2014; 27 (1).

[72] Viala-Gaudefroy J., Lindaman D. Donald Trump's "Chinese virus:” The politics of naming. Conversation. 2020, April 21.

[73] Von der Leyen U. A global pandemic requires a world effort to end it: None of us will be safe until everyone is safe. URL: https://www.who.int/news-room/commentaries/detail/aglobal-pandemic-requires-a-world-effort-to-end-it-none-of-us-will-be-safe-until-everyoneis-safe.

[74] Walker P. Covid: Jenrick defends decision to ignore Sage's lockdown advice. Guardian. 2020, October 13.

[75] Whitehead M, Barr B, Taylor-Robinson D. Covid-19: We are not "all in it together:" Less privileged in society are suffering the brunt of the damage. BMJ Opinion. 2020, May 22.

[76] Williams M.C. Words, images, enemies: Securitization and international politics. International Studies Quarterly. 2003; 47 (4).

[77] Xi focus: Xi vows to win people's war against novel coronavirus. Xinhua. 2020, February 11.

[78] Yi-Chong X., Weller P. "To be, but not to be seen:” Exploring the impact of international civil servants. Public Administration. 2008; 86 (1).

[79] Zaleznik A. Power and politics in organizational life. URL: https://hbr.org/1970/05/powerand-politics-in-organizational-life.

[80] Zarocostas J. How to fight an infodemic. Lancet. 2020, February 29.

[81] Žižek S. Barbarism with a human face. Welt. 2020, March 19. 


\title{
Безответственное участие: роль правительств, экспертов на местах и публичных интеллектуалов в условиях пандемии covid-19*
}

\author{
Б. Раделжич ${ }^{1,2}$, К. Гонсалес-Вилья ${ }^{3}$ \\ ${ }^{1}$ Университет Некметтина Эрбакана \\ Дере Ашиклар Мах., Демеч Сок. № 39/1, 42140 Мерам/Конья, Туричия \\ ${ }^{2}$ Университет Антонио де Небриха \\ ул. Санта Круз де Маркенадо, 28015, Мадрид, Испания \\ ${ }^{3}$ Университет Кастилии-Ла-Манча \\ Кобертизо де Сан Педро Мартир S/N, 45071 Толедо, Испания \\ (e-mail: radeljic@erbakan.edu.tr; BRadeljic@nebrija.es; Carlos.GonzalezVilla@uclm.es)
}

\begin{abstract}
Аннотация. Пандемия новой коронавирусной инфекции стала огромным шоком для всего мирового сообщества. В попытках встроить свои ответные реакции на глобальный кризис в собственные условия выживания национальные правительства выбрали путь аргументации, который позволяет им снижать меру своей ответственности за происходящее перед населением. Несмотря на то, что в современных обществах именно эксперты, как считалось прежде, занимают привилегированную позицию, в сложившихся условиях они оказались вытеснены из процессов принятия решений на правительственном уровне, а их оценки были делегитимизированы вследствие мощного антиинтеллектуального движения, сложившегося благодаря характерной для социальных сетей модели аргументации и ведения дискуссий. В то же время, хотя публичные интеллектуалы считаются носителями инсайдерской информации, позволяющей им давать обоснованные оценки специфических явлений и отличать правду от большой лжи (и весь спектр явлений между ними), их роль в условиях нынешней пандемии была серьезно ограничена. В статье анализируются ответы правительств ключевых геополитических игроков и региональных лидеров на коронавирусный кризис с точки зрения используемых дискурсивных приемов, а также способность экспертов и публичных интеллектуалов противостоять этим дискурсивным практикам. Как своего рода «главные редакторы», политические лидеры увлеклись военной метафорой, чтобы провести деконструкцию сложных областей действительности и ее субъектов, сделав их понятными и доступными, и тем самым обеспечили достаточный уровень общественного внимания и поддержки для провозглашенной ими борьбы с врагом. Кроме того, они смогли ввести чрезвычайные меры, которые в условиях геополитического противостояния обеспечили им возможность избежать личной ответственности. Вместо того, чтобы на основе своих знаний обеспечить конструктивный анализ сложных проблем и объяснить их таким образом, чтобы население могло понять суть избранных руководством страны мер и минимизировать свои потери во все усложняющейся конкурентной среде, эксперты и интеллектуалы внезапно обнаружили, что их возможности маневра для влияния на управленческие решения жестко ограничены.
\end{abstract}

Ключевые слова: covid-19 (коронавирус); исполнительная власть; эксперты на местах; публичные интеллектуалы; военная метафора; секьюритизация

\section{Информация о финансировании}

Исследование Карлоса Гонсалеса-Вильи проводится при поддержке Фонда Европейского регионального развития (проект № 2020/3771).

\footnotetext{
* ( ) Раделжич Б., Гонсалес-Вилья К., 2021

Статья поступила 31.05.2021 г. Статья принята к публикащии 28.09.2021 г.
} 